\title{
Mineral content, based in the Recommended Daily Intake, in cashew nut obtained from conventional and organic cultivation in different stages of processing
}

\section{Teor de minerais, baseado na Ingestão Diária Recomendada, em castanhas de caju obtidas dos cultivos convencional e orgânico em diferentes etapas de processamento}

\author{
Denise Josino Soares ${ }^{1 *}$; Luiz Bruno de Sousa Sabino; \\ Marina Silveira Machado Lanicca de Sousa²; \\ Carlos Emanuel de Carvalho Magalhães ${ }^{3}$; Maria Mozarina Bezerra Almeida ${ }^{4}$; \\ Paulo Henrique Machado de Sousa ${ }^{5}$; Raimundo Wilane de Figueiredo ${ }^{6}$
}

\begin{abstract}
The cashew nut has a high nutritional value since it is a source of protein, fatty acids and carbohydrates. The minerals quantification in food is important, since these are important constituents from the nutritional point of view. Given the above, this research aimed to characterize and quantify the minerals of the cashew nuts from conventional and organic cultivation during various stages of processing with emphasis in the Recommended Daily Intake of these minerals. The study was performed with cashew nuts collected at four stages of processing (after shelling, before peeling, after peeling and packing). The minerals sodium, potassium, calcium, magnesium, iron, copper, zinc, manganese, cobalt, nickel and selenium were quantified. The nuts presented good content of all minerals studied. There was little variation in the content of the potassium, magnesium, zinc and cobalt minerals during the processing. The cashew nuts from conventional cultivation presented similar content of minerals to the nuts from organic cultivation.
\end{abstract}

Key words: Food processing, organic foods, nutritional values, oligoelements

\section{Resumo}

A castanha de caju possui elevado valor nutricional por ser fonte de proteína, ácidos graxos e carboidratos. A quantificação dos minerais em alimentos é importante, já que estes constituintes são muito importantes do ponto de vista nutricional. Diante do exposto, essa pesquisa teve como objetivo caracterizar e quantificar os minerais na amêndoa de castanha de caju dos cultivos convencional e orgânico em diferentes etapas de processamento com ênfase à Ingestão Diária Recomendada destes minerais. $\mathrm{O}$ estudo foi realizado com amêndoas de castanha de caju coletadas em quatro etapas da linha

\footnotetext{
${ }^{1}$ Discente do Curso de Doutorado em Ciência e Tecnologia de Alimentos, Universidade Federal do Ceará, UFC, Fortaleza, CE. E-mail: denisejosino@hotmail.com

${ }^{2}$ Discentes do Curso de Graduação em Engenharia de Alimentos, UFC, Fortaleza, CE. E-mail: luno_ss@hotmail.com; marininha_143@hotmail.com

${ }^{3}$ Prof. Dr. do Centro de Ciências e Tecnologia, Universidade Estadual do Ceará, UECE, Fortaleza, CE. E-mail: cecmagal@yahoo.com.br

${ }^{4}$ Prof. Dr. do Dept ${ }^{\mathrm{o}}$ de Química Analítica e Físico-Química, UFC, Fortaleza, CE. E-mail: mozarina@gmail.com

${ }^{5}$ Prof. Dr. do Instituto de Cultura e Arte, UFC, Fortaleza, CE. E-mail: phenriquemachado@gmail.com

${ }^{6}$ Prof. Dr. do Dept ${ }^{\circ}$ de Tecnologia de Alimentos, UFC, Fortaleza, CE. E-mail: figueira@ufc.br

${ }^{*}$ Author for corespondence
} 
de processamento (após a decorticação, antes da despeliculagem, após a despeliculagem e embalagam). Os minerais sódio, potássio, cálcio, magnésio, ferro, cobre, zinco, manganês, cobalto, níquel e selênio foram quantificados. As amêndoas apresentaram boas quantidades de todos os minerais estudados. Ocorreu pequena variação no conteúdo dos minerais potássio, magnésio, zinco e cobalto durante o processamento. As amêndoas de castanha de caju de cultivo convencional apresentaram teores de minerais semelhantes aos das amêndoas de cultivo orgânico.

Palavras-chave: Processamento de alimentos, alimentos orgânicos, valor nutricional, oligoelementos

\section{Introduction}

The nuts, in general, have received particular attention due to their nutritional properties that minimize the problems of cardiovascular disease (ALEXIADOU; KATSILAMBROS, 2011) when they are consumed at higher doses then the minimum recommended (SEGURA et al., 2006).

These benefits of nuts consumption occurs because they are sources of important compounds to the body such the minerals manganese, calcium, iron, copper, chromium, arsenic and selenium which act as cofactors in many physiological and metabolic functions (YANG, 2009). Due to the high importance of the minerals to the human healthy, their determination in foods is important from the nutritional point of view (CABRERA et al., 2003).

The processing of cashew nuts includes the following stages: harvesting of cashew, removal of the cashew nut, cleaning, selection, drying, classification, cooking, shelling, drying, humidification, cooling, peeling, packing and storage (PAIVA; SILVA NETO; PESSOA, 2000). During the processing of fruits losses in some compounds occur and there are few studies on this aspect. It is important to understand the influence of the processing and the preservation technology on the chemical composition of food (TUDELA; ESPÍN; GIL, 2002; ZHANG; HAMAUZU, 2004).

The constant search for healthy foods has led to changes in food production systems such as from conventional to organic cultivation. The food cultivation through the conventional farming allows the use of fertilizers and pesticides. In organic cultivation the use of these substances is not allowed (CHITARRA; CHITARRA, 2005). However, little is known whether there is any variation in the chemical composition of foods obtained from this cultivation system when compared to the conventional system.

Given the above, this research aimed to characterize and quantify the minerals of the cashew nuts from conventional and organic cultivation during various stages of processing, with emphasis in the Recommended Daily Intake of these minerals.

\section{Material and Methods}

The study was performed with cashew nuts from conventional and organic cultivation given by a large company located in the city of Mossoró (Rio Grande do Norte, Brazil). These two cultivation forms studied were cultivated at the same farm, with the same environmental conditions and belonged to the same specie (Anacardium occidentale) and variety (early dwarf cashew trees).

At the shelling step the shell is opened and separated from the nut. After this step, the drying is performed at $80^{\circ} \mathrm{C}$ until nut moisture close to $3.0 \%$, followed by cooling at room temperature. The following steps are to removal the film (peeling), selection, classification and packing.

The cashew nuts were collected at four stages of processing: after shelling, before peeling, after peeling and packing. These steps were selected in order to check if there were losses of the mineral content during the processing of these nuts.

The samples were crushed in a domestic blender to obtain a meal, and then were freeze-dried. $1 \mathrm{~g}$ of the freeze-dried meal was weighed in tubes 
previously washed with hydrochloric acid 5\% solution, rinsed with deionized water and dried. 10 $\mathrm{mL}$ of the oxidant mixture of nitric acid: perchoric acid (3:1) was added. This mixture was placed in a heated plate, and the temperature was increased gradually to $220^{\circ} \mathrm{C}$ until the complete digestion of the organic matter and consequently a clear liquid was obtained. When it was necessary, $5 \mathrm{~mL}$ of nitric acid: perchloric acid (3:1) was added. The final solution was filtered to a $100 \mathrm{~mL}$ volumetric flask with deionized water.

The minerals sodium, potassium, calcium, magnesium, iron, copper, zinc, manganese, cobalt, nickel and selenium were quantified by atomic absorption spectrometry. For the calcium, magnesium, iron, zinc and manganese quantification was performed with a flame atomic absorption spectrometer (model Atomica-GBC 933 Plus) calibrated with the wavelength, slit and gas mixture specific to each element. In the cobalt, nickel and selenium quantification the spectrometry Varian (model SpectrAA 220) was used with background correction system for the longitudinal Zeeman effect, equipped with graphite furnace atomizer and hollow cathode lamp as a radiation source, following the program for pipe warm-up recommended by the manufacturer. The calibration curves were prepared using ampoules of the standards for atomic absorption Merck, properly diluted with deionized water. The minerals $\mathrm{Na}$ and $\mathrm{K}$ were analyzed by flame photometry (Analyser, 910M). The operating conditions of the analysis are summarized in Table 1.

Table 1. Operating conditions used in the quantification of minerals in cashew nuts from conventional and organic cultivation.

\begin{tabular}{ccccc}
\hline Minerals & Technique & $\lambda_{\text {nm }}$ & Linear Range & Reference \\
\hline $\mathrm{Na}$ & $\mathrm{FF}$ & 589.0 & - & AOAC (1980) \\
$\mathrm{K}$ & $\mathrm{FF}$ & 766.5 & - & AOAC (1980) \\
$\mathrm{Ca}$ & FAAS & 422.7 & $1.0-5.0 \mathrm{mg} \cdot \mathrm{L}^{-1}$ & Welz (1999) \\
$\mathrm{Mg}$ & FAAS & 285.2 & $0.1-0.5 \mathrm{mg} \cdot \mathrm{L}^{-1}$ & Welz (1999) \\
$\mathrm{Fe}$ & FAAS & 248.3 & $1.0-5.0 \mathrm{mg} \cdot \mathrm{L}^{-1}$ & Christian (2003) \\
$\mathrm{Cu}$ & FAAS & 324.7 & $0.03-10 \mathrm{mg} \cdot \mathrm{L}^{-1}$ & Welz (1999) \\
$\mathrm{Zn}$ & FAAS & 213.9 & $0.1-0.4 \mathrm{mg} \cdot \mathrm{L}^{-1}$ & Welz (1999) \\
$\mathrm{Mn}$ & FAAS & 279.5 & $1.0-5.0 \mathrm{mg} \cdot \mathrm{L}^{-1}$ & Welz (1999) \\
$\mathrm{Co}$ & GFAA & 242.5 & $0-35 \mu \mathrm{g} . \mathrm{L}^{-1}$ & Welz (1999) \\
$\mathrm{Ni}$ & GFAA & 232.5 & $0-35 \mu \mathrm{g} \cdot \mathrm{L}^{-1}$ & Welz (1999) \\
$\mathrm{Se}$ & GFAA & 196.2 & $0-33 \mu \mathrm{g} \cdot \mathrm{L}^{-1}$ & Welz (1999) \\
\hline
\end{tabular}

FF: Flame Photometry; FAAS: Flame Atomic Absorption Spectrometry; and EAAFG: Graphite-Furnace Atomic Absorption. Source: Elaboration of the authors.

There were three collections during the months of October 2009 and February 2010 and two samples were taken at the time of each collection, one from a conventional source, the other from an organic source.

The experiment was conducted in a randomized block design using four stages of the processing line (four points of collection) in the parcels and two cultivation forms (conventional and organic cultivation) in the sub parcels with three replications.

The results were statistically evaluated by variance analysis. As evidenced the significant by the F test, the treatments were compared by Tukey test at 5\% probability using the SAS Statistical Software version 8.1 (SAS, 2006). 


\section{Results and Discussion}

The average value of sodium was $14.85 \pm 2.57$ $\mathrm{mg} / 100 \mathrm{~g}$ (Table 2). No significant difference $(\mathrm{p}>0.05)$ between the two cultivation forms and between the four stages of processing was evident. Sousa et al. (2011) studied the mineral content in the cashew nut from Brazilian Savanna and observed average values of $3.08 \mathrm{mg} / 100 \mathrm{~g}$ of sodium, which is much lower than observed in the present study.

Table 2. Mean \pm standard deviation of the minerals in cashew nuts obtained from conventional (Conv.) and organic (Org.) cultivation in different stages of processing and overall mean \pm standard.

\begin{tabular}{|c|c|c|c|c|c|c|}
\hline \multirow{2}{*}{ Minerals } & \multirow{2}{*}{ Cultivation } & \multicolumn{4}{|c|}{ Stages of processing } & \multirow{2}{*}{$\begin{array}{c}\text { Mean } \\
\pm \text { standard }\end{array}$} \\
\hline & & After shelling & Before peeling & After peeling & Packing & \\
\hline \multirow{2}{*}{$\begin{array}{c}\mathrm{Na} \\
(\mathrm{mg} / 100 \mathrm{~g})\end{array}$} & Conv. & $15.25 \pm 1.87$ & $13.44 \pm 1.83$ & $16.84 \pm 0.47$ & $14.01 \pm 0.90$ & \multirow{2}{*}{$14.85 \pm 2.57$} \\
\hline & Org. & $13.43 \pm 0.38$ & $19.36 \pm 2.67$ & $14.29 \pm 1.27$ & $12.03 \pm 0.67$ & \\
\hline \multirow{2}{*}{$\begin{array}{c}\mathrm{K} \\
(\mathrm{mg} / 100 \mathrm{~g})\end{array}$} & Conv. & $143.88 \pm 9.49$ & $160.37 \pm 4.12$ & $182.51 \pm 15.71$ & $109.02 \pm 14.91$ & \multirow{2}{*}{$144.33 \pm 26.19$} \\
\hline & Org. & $152.51 \pm 24.20$ & $162.55 \pm 34.18$ & $136.66 \pm 32.15$ & $107.14 \pm 38.01$ & \\
\hline \multirow{2}{*}{$\begin{array}{c}\mathrm{Ca} \\
(\mathrm{mg} / 100 \mathrm{~g})\end{array}$} & Conv. & $3.04 \pm 0.24$ & $3.03 \pm 0.35$ & $2.89 \pm 0.30$ & $3.37 \pm 0.13$ & \multirow{2}{*}{$3.58 \pm 0.73$} \\
\hline & Org. & $3.88 \pm 0.77$ & $4.63 \pm 0.94$ & $4.11 \pm 0.42$ & $3.42 \pm 0.03$ & \\
\hline \multirow{2}{*}{$\begin{array}{c}\mathrm{Mg} \\
(\mathrm{mg} / 100 \mathrm{~g})\end{array}$} & Conv. & $74.62 \pm 8.16$ & $70.72 \pm 6.09$ & $54.51 \pm 4.33$ & $60.87 \pm 5.52$ & \multirow{2}{*}{$61.27 \pm 13.16$} \\
\hline & Org. & $75.39 \pm 4.01$ & $58.96 \pm 1.74$ & $63.09 \pm 4.23$ & $50.98 \pm 9.68$ & \\
\hline \multirow{2}{*}{$\begin{array}{c}\mathrm{Fe} \\
(\mathrm{mg} / 100 \mathrm{~g})\end{array}$} & Conv. & $2.61 \pm 0.21$ & $3.02 \pm 0.67$ & $2.87 \pm 0.19$ & $2.61 \pm 0.54$ & \multirow{2}{*}{$2.61 \pm 0.51$} \\
\hline & Org. & $2.39 \pm 0.07$ & $2.72 \pm 0.18$ & $2.79 \pm 0.20$ & $2.35 \pm 0.29$ & \\
\hline \multirow{2}{*}{$\begin{array}{c}\mathrm{Cu} \\
(\mathrm{mg} / 100 \mathrm{~g})\end{array}$} & Conv. & $1.04 \pm 0.08$ & $0.96 \pm 0.06$ & $0.97 \pm 0.14$ & $0.92 \pm 0.21$ & \multirow{2}{*}{$0.95 \pm 0.19$} \\
\hline & Org. & $1.02 \pm 0.07$ & $1.07 \pm 0.11$ & $0.96 \pm 0.04$ & $0.93 \pm 0.25$ & \\
\hline \multirow{2}{*}{$\begin{array}{c}\mathrm{Zn} \\
(\mathrm{mg} / 100 \mathrm{~g})\end{array}$} & Conv. & $5.28 \pm 1.87$ & $2.41 \pm 0.04$ & $3.11 \pm 0.52$ & $2.35 \pm 0.45$ & \multirow{2}{*}{$2.89 \pm 1.20$} \\
\hline & Org. & $2.59 \pm 0.21$ & $2.66 \pm 0.23$ & $2.79 \pm 0.26$ & $1.90 \pm 1.06$ & \\
\hline \multirow{2}{*}{$\begin{array}{c}\mathrm{Mn} \\
(\mathrm{mg} / 100 \mathrm{~g})\end{array}$} & Conv. & $0.77 \pm 0.05$ & $0.80 \pm 0.16$ & $0.70 \pm 0.11$ & $0.74 \pm 0.11$ & \multirow{2}{*}{$0.76 \pm 0.16$} \\
\hline & Org. & $0.89 \pm 0.07$ & $0.84 \pm 0.09$ & $0.81 \pm 0.05$ & $0.55 \pm 0.33$ & \\
\hline \multirow{2}{*}{$\begin{array}{c}\text { Co } \\
(\mathrm{mg} / 100 \mathrm{~g})\end{array}$} & Conv. & $0.32 \pm 0.10$ & $0.25 \pm 0.05$ & $0.08 \pm 0.01$ & $0.36 \pm 0.11$ & \multirow{2}{*}{$0.24 \pm 0.11$} \\
\hline & Org. & $0.30 \pm 0.04$ & $0.28 \pm 0.03$ & $0.18 \pm 0.05$ & $0.17 \pm 0.10$ & \\
\hline \multirow{2}{*}{$\begin{array}{c}\mathrm{Ni} \\
(\mathrm{mg} / 100 \mathrm{~g})\end{array}$} & Conv. & $0.68 \pm 0.42$ & $0.41 \pm 0.03$ & $0.66 \pm 0.14$ & $0.58 \pm 0.11$ & \multirow{2}{*}{$0.60 \pm 0.48$} \\
\hline & Org. & $0.36 \pm 0.03$ & $0.42 \pm 0.02$ & $0.56 \pm 0.04$ & $0.47 \pm 0.18$ & \\
\hline \multirow{2}{*}{$\begin{array}{c}\text { Se } \\
(\mu \mathrm{g} / 100 \mathrm{~g})\end{array}$} & Conv. & $22.41 \pm 5.12$ & $23.66 \pm 1.78$ & $21.97 \pm 2.02$ & $21.45 \pm 1.84$ & \multirow{2}{*}{$22.82 \pm 3.66$} \\
\hline & Org. & $27.37 \pm 4.56$ & $21.30 \pm 0.72$ & $25.32 \pm 3.17$ & $19.12 \pm 4.04$ & \\
\hline
\end{tabular}

Source: Elaboration of the authors.

There was no significant interaction $(p>0.05)$ between the two forms of cultivation and there was significant interaction $(p<0.05)$ between the stages of the processing for the mineral potassium indicating that were significant difference $(p<0.05)$ between the four stages of the processing. In order to check in which stage of processing this difference was occurring, the Tukey test was performed (Table $3)$. The lowest value was observed in nuts collected at the packing (108.08 mg/100 g) (Table 3). There was reduction in potassium content during the processing. 
Table 3. Mean values of the mineral potassium in cashew nuts from conventional and organic cultivation in different stages of processing."

\begin{tabular}{cccc}
\hline Collection stages & Conventional & Organic & Potassium $(\mathrm{mg} / 100 \mathrm{~g})$ \\
\hline After shelling & $143.88 \pm 9.49$ & $152.51 \pm 24.20$ & $148.20^{\mathrm{a}}$ \\
Before peeling & $160.37 \pm 4.12$ & $162.55 \pm 34.18$ & $161.46^{\mathrm{a}}$ \\
After peeling & $182.51 \pm 15.71$ & $136.66 \pm 32.15$ & $159.58^{\mathrm{a}}$ \\
Packing & $109.02 \pm 14.91$ & $107.14 \pm 38.01$ & $108.08^{\mathrm{b}}$ \\
\hline
\end{tabular}

* Same letters within the same column are not statistically different by Tukey test $(\mathrm{p} \leq 0.05)$.

Source: Elaboration of the authors.

The average of this mineral was $144.33 \pm 26.19$ $\mathrm{mg} / 100 \mathrm{~g}$ (Table 2). This value is lower than that reported by Naozuka et al. (2011) and Sousa et al. (2011), who observed averages of potassium of $730.1 \mathrm{mg} / 100 \mathrm{~g}$ in cashew nut from Brazilian Northeastern and $556.16 \mathrm{mg} / 100 \mathrm{~g}$ in cashew nut from Brazilian Savanna, respectively. In Brazil nuts, the average reported by Naozuka et al. (2011) was $507.0 \mathrm{mg} / 100 \mathrm{~g}$.

There are no data in the literature about the Recommended Daily Intake (RDI) for the mineral potassium, but it is known that increasing the intake of this mineral lowers blood pressure and decreases the incidence of stroke. In addition, potassium also has a beneficial effect on the heart and bone demineralization (SEGURA et al., 2006).

The cashew nut is not recognized as a good source of calcium. The average results observed in this study $(3.58 \pm 0.73 \mathrm{mg} / 100 \mathrm{~g}$ ) (Table 2) are lower than those observed by Naozuka et al. (2011) (24.2 mg/100 g) and Sousa et al. (2011) in cashew nut.

Calcium is the most abundant mineral in the human body and is a vital electrolyte, since it is part of several biological functions such as nerve conduction, muscle contraction and blood clotting (SEGURA et al., 2006). Due to this, it is extremely important to search for food sources of this mineral.

There was significant interaction $(p<0.05)$ between the stages of the processing and the cultivation methods for the minerals magnesium, zinc and cobalt, which indicated that there were significant difference $(p<0.05)$ between the two forms of cultivation, either between the four stages of the processing, or between both (cultivation forms and stages of processing together). Because of the significant interaction for those three minerals, the Tukey test had to be performed and the data about this interaction is shown in Table 4.

The average magnesium content in the present study $(61.27 \pm 13.16 \mathrm{mg} / 100 \mathrm{~g})$ (Table 2) was lower than that reported by Naozuka et al. (2011) (279.4 $\mathrm{mg} / 100 \mathrm{~g})$ and Sousa et al. (2011) (277.09 mg/100 g) in cashew nut.

There was reduction in the magnesium content in nuts from organic cultivation during the processing, the highest value was found in nuts collected after shelling $(75.39 \mathrm{mg} / 100 \mathrm{~g})$ and differed significantly $(\mathrm{p}<0.05)$ from nuts collected at the packing $(50.98$ $\mathrm{mg} / 100 \mathrm{~g}$ ) (Table 4). 
Table 4. Mean values of the minerals magnesium, zinc and cobalt in cashew nuts from conventional and organic cultivation in different stages of processing."

\begin{tabular}{ccccccc}
\hline \multirow{2}{*}{ Collection stages } & \multicolumn{2}{c}{ Magnesium $(\mathrm{mg} / 100 \mathrm{~g})$} & \multicolumn{2}{c}{ Zinc $(\mathrm{mg} / 100 \mathrm{~g})$} & \multicolumn{2}{c}{ Cobalt $(\mathrm{mg} / 100 \mathrm{~g})$} \\
\cline { 2 - 7 } & Conventional & Organic & Conventional & Organic & Conventional & Organic \\
\hline After shelling & $66.10^{\mathrm{a}}$ & $75.39^{\mathrm{a}}$ & $5.28^{\mathrm{a}}$ & $2.59^{\mathrm{a}}$ & $0.32^{\mathrm{a}}$ & $0.30^{\mathrm{a}}$ \\
Before peeling & $70.72^{\mathrm{a}}$ & $58.96^{\mathrm{ab}}$ & $2.41^{\mathrm{b}}$ & $2.66^{\mathrm{a}}$ & $0.25^{\mathrm{ab}}$ & $0.28^{\mathrm{a}}$ \\
After peeling & $54.51^{\mathrm{a}}$ & $63.09^{\mathrm{ab}}$ & $3.11^{\mathrm{ab}}$ & $2.79^{\mathrm{a}}$ & $0.18^{\mathrm{b}}$ & $0.18^{\mathrm{a}}$ \\
Packing & $60.88^{\mathrm{a}}$ & $50.98^{\mathrm{b}}$ & $2.35^{\mathrm{b}}$ & $1.90^{\mathrm{a}}$ & $0.36^{\mathrm{a}}$ & $0.17^{\mathrm{a}}$ \\
\hline
\end{tabular}

* Same letters within the same column are not statistically different by Tukey test $(\mathrm{p} \leq 0.05)$.

Source: Elaboration of the authors.

The average observed in this study indicates that in $100 \mathrm{~g}$ of cashew nut it is possible get approximately $15.32 \%$ of the RDI of magnesium, which, according to FAO (2011), is $400 \mathrm{mg}$ based on a caloric intake of 2000 calories. These results highlight the importance of eating this nut, since according to Saris et al. (2000), the magnesium is an intracellular cation essential to over 300 enzymatic reactions, is involved in glucose utilization in energy metabolism, in protein and fatty acid synthesis and almost all hormonal reactions. Casas-Agustench et al. (2011), claim that the ingestion of foods which are a source of magnesium and calcium is recommended for hypertensive patients.

According to Segura et al. (2006), the nuts have a substantial amount of the minerals calcium, magnesium and potassium and low content of sodium. These same authors claim that the association of these minerals in the amounts found in nuts contributes to the prevention of diabetes and coronary heart disease.

Cabrera et al. (2003) studied the iron content in different nuts and observed averages of $4.5 \mathrm{mg} / 100$ $\mathrm{g}$ in almond, $1.42 \mathrm{mg} / 100 \mathrm{~g}$ in cashew nut, 1.73 $\mathrm{mg} / 100 \mathrm{~g}$ in hazelnut, $2.28 \mathrm{mg} / 100 \mathrm{~g}$ in peanut and $7.35 \mathrm{mg} / 100 \mathrm{~g}$ in pistachio. In the present study, the observed value was $2.61 \pm 0.51 \mathrm{mg} / 100 \mathrm{~g}$ (Table 2), this value is only lower than the value observed in almond and pistachio.

The average observed of copper was $0.95 \pm 0.19$ $\mathrm{mg} / 100 \mathrm{~g}$ (Table 2), which is in the good content according to recommended by FAO (2011), which is $2 \mathrm{mg}$ based on a caloric intake of 2000 calories. These values are higher than those observed by Cabrera et al. (2003) $(0.78 \mathrm{mg} / 100 \mathrm{~g})$ and Naozuka et al. $(2011)(0.61 \mathrm{mg} / 100 \mathrm{~g})$ in cashew nuts. In other nuts, Cabrera et al. (2003) observed values of 1.11 $\mathrm{mg} / 100 \mathrm{~g}$ in almonds, $1.66 \mathrm{mg} / 100 \mathrm{~g}$ in hazelnuts, $0.69 \mathrm{mg} / 100 \mathrm{~g}$ in peanuts and $0.92 \mathrm{mg} / 100 \mathrm{~g}$ in pistachios and Welma, Klimpel and Zyrnick (2008) (1.96 mg/100 g in Brazil nut).

Zinc has high importance, because it has antioxidant proprieties. Its content is limited in plant foods (SOUSA et al., 2011). In the present study the content observed was $2.89 \pm 1.20 \mathrm{mg} / 100$ g (Table 2) which corresponds to $19.27 \%$ of the RDI for adults and children with a caloric intake of 2000 calories (FAO, 2011). Naozuka et al. (2011) and Sousa et al. (2011), studying the cashew nut observed higher values than in the present study. These authors reported values of $5.4 \mathrm{mg} / 100 \mathrm{~g}$ and $4.98 \mathrm{mg} / 100 \mathrm{~g}$, respectively.

There was no significant difference $(p>0.05)$ between the different steps of processing in nuts from organic farming for the mineral zinc (Table 4). In the nuts from conventional cultivation, there was a reduction between the steps of processing, which the maximum value was $5.28 \mathrm{mg} / 100 \mathrm{~g}$ (after shelling) and the minimum was $2.35 \mathrm{mg} / 100 \mathrm{~g}$ (packing), presenting significant difference $(\mathrm{p}<0.05)$ between these two steps of processing (Table 4 ).

The average of manganese was $0.76 \pm 0.16$ 
$\mathrm{mg} / 100 \mathrm{~g}$ (Table 2). The RDI for this mineral is $2.0 \mathrm{mg}$ (based on a caloric intake of 2,000 calories) (FAO, 2011), which corresponds to $38 \%$ of the value observed in this study. Naozuka et al. (2011) and Welma, Klimple and Zyrnick (2008) observed values of $0.88 \mathrm{mg} / 100 \mathrm{~g}$ and $1.01 \mathrm{mg} / 100 \mathrm{~g}$ in Brazil nuts.

The average of the mineral cobalt was $0.24 \pm$ $0.11 \mathrm{mg} / 100 \mathrm{~g}$ (Table 2). There are no literature data about the RDI of this mineral. There was no significant difference $(p>0.05)$ between the steps of processing in nuts from organic cultivation (Table 4).

The observed average of the nickel mineral was $0.60 \pm 0.48 \mathrm{mg} / 100 \mathrm{~g}$ (Table 2), which was lower than that observed by Welma, Klimpel and Zurnick (2008) $(0.88 \mathrm{mg} / 100 \mathrm{~g})$ and higher than that observed by Cabrera et al. (2003) $(0.017 \mathrm{mg} / 100 \mathrm{~g})$. The result observed in this study was superior to that reported by Cabrera et al. (2003) in other types of nuts. These authors found values of $0.031 \mathrm{mg} / 100 \mathrm{~g}$ in almond, $0.038 \mathrm{mg} / 100 \mathrm{~g}$ hazelnut, $0.025 \mathrm{mg} / 100$ $\mathrm{g}$ in peanut and $0.027 \mathrm{mg} / 100 \mathrm{~g}$ in pistachio.

Selenium showed an average of $22.82 \pm 3.66$ $\mu \mathrm{g} / 100 \mathrm{~g}$ (Table 2). Sousa et al. (2011), observed lower values in cashew nuts $(1.02 \mu \mathrm{g} / 100 \mathrm{~g})$ than those observed in the present study.

The differences observed in mineral content between the different authors and the present study can occur as a result of several factors. According to Nassu, Lima and Paiva (2004) the components of fruits can change due to growing conditions, climate, stage of maturity and method used in their quantification.

There was no significant difference $(p<0.05)$ in the levels of each mineral studied between conventional and organic cultivation (except calcium and zinc), indicating that these agricultural practices do not cause a reduction or increase of these components in cashew nuts.

\section{Conclusions}

The cashew nut showed significant values of the minerals studied, particularly with regard to its copper content corresponding to $47.5 \%$ of recommended daily intake for adults.

Few changes in the content of the minerals potassium, magnesium, zinc and cobalt were observed during the processing of nuts. The other minerals studied did not change during processing.

The conventional cultivation of cashew nut had a similar content of minerals to that found in cashew nuts from organic cultivation, except for of the minerals calcium and zinc.

\section{References}

ALEXIADOU, K.; KATSILAMBROS, N. Nuts: Anti-atherogenic food? European Journal of Internal Medicine, Milan, v. 22, n. 2, p. 141-146, 2011.

ASSOCIATION OF OFFICIAL ANALYTICAL CHEMISTRY - AOAC. Official methods of analysis. 13. ed. Washington, D.C: AOAC International, 1980. 1015 p.

CABRERA, C.; LLORIS, F.; GIMÉNEZ, R.; OLALLA, M.; LÓPEZ, M. C. Mineral content in legumes and nuts: contribution to the Spanish dietary intake. Science of the Total Environment, Madison, v. 308, n. 1-3, p. 1-14, 2003.

CASAS-AGUSTENCH, P.; LÓPEZ-URIARTE， P.; ROS, E.; BULLÓ, M.; SALAS-SALVADÓ, J. Nuts, hypertension and endothelial function. Nutrition, Metabolism \& Cardiovascular Diseases, Naples, v. 21, p. 21-33, 2011. Supplement 1.

CHITARRA, M. I. F.; CHITARRA, A. B.. Pós-colheita de frutas e hortaliças: fisiologia e manuseio. 2. ed. Universidade Federal de Lavras: UFLA, 2005. 783 p.

CHRISTIAN, G. D. Analytical chemistry. 6. ed. New York: John Wiley \& Sons, 2003. 848 p.

FOOD AND DRUG ADMINISTRATION - FAO. 2011. Appendix $F$ : calculate the percent daily value for the appropriate nutrients. Available at: $<$ http://www.fda.gov/ Food/default.htm>. Accessed at: 23 nov. 2011. 
NAOZUKA, J.; VIEIRA, E. C.; NASCIMENTO, A. N.; OLIVEIRA, P. V. Elemental analysis of nuts and seeds by axially viewed ICP OES. Food Chemistry, Oxford, v. 124, n. 4, p. 1667-1672, 2011.

NASSU, R. T.; LIMA, J. R; PAIVA, F. F. A. Boas práticas no processamento de castanha de caju. Fortaleza: Embrapa Agroindústria Tropical, 2004. 36 p.

PAIVA, F. F. A.; SILVA NETO, R. M.; PESSOA, P. F. A. P. Minifábrica de processamento de castanha de caju. Fortaleza: Embrapa Agroindústria Tropical, 2000. 22 p.

SARIS, N. E.; MERVAALA, E.; KARPPANEN, H.; KHAWAJA, J. A.; LEWENSTAM, A. Magnesium: An update on physiological, clinical and analytical aspects. Clinica Chimica Acta, Gent, v. 294, n. 1-2, p. 1-26, 2000.

SAS Institute. SAS/STAT ${ }^{\circledR}$. User's guide: statistics. Version 8.1. 4. ed. Cary: SAS Institute, 2006.

SEGURA, R.; JAVIERRE, C.; LIZARRAGA, M. A.; ROS, E. Other relevant components of nuts: phytosterols, folate and minerals. British Journal of Nutrition, Cambridge, v. 96, p. 36-44, 2006. Supplement 2.
SOUSA, A. G. O.; FERNANDES, D. C.; ALVEZ, A. M.; FREITAS, J. B.; NAVES, M. M. V. Nutritional quality and protein value of exotic almonds and nut from the Brazilian Savanna compared to peanut. Food Research International, Guelph, v. 44, n. 7, p. 2319-2325, 2011.

TUDELA, J. A.; ESPÍN, J. C.; GIL, M. I. Vitamin C retention in fresh-cut potatoes. Postharvest Biology and Technology, Pullman, v. 26, n. 1, p. 75-84, 2002.

WELMA, M.; KLIMPEL, M.; ZYRNICKI, W. Investigation of major and trace elements and their distributions between lipid and non-lipid fractions in Brazil nuts by inductively coupled plasma atomic optical spectrometry. Food Chemistry, Oxford, v. 111, n. 4, p. 1012-1015, 2008.

WELZ, B. Atomic absorption spectrometry. 3. ed. Deerfield: VCH, 1999. 941 p.

YANG, J. Brazil nuts and associated health benefits: a review. Food Science and Technology, London, v. 42, n. 10, p. 1573-1580, 2009.

ZHANG, D.; HAMAUZU, Y. Phenolics, ascorbic acid, carotenoids and antioxidant activity of broccoli and their changes during conventional and microwave cooking. Food Chemistry, Oxford, v. 88, n. 4, p. 503-509, 2004. 